\title{
Selection of Mx gene genotype as genetic marker for Avian Influenza resistance in Indonesian native chicken
}

\author{
Tike Sartika ${ }^{1 *}$, Sri Sulandari ${ }^{2 \dagger}$, Moch Syamsul Arifin Zein ${ }^{2+}$ \\ From International Symposium on Animal Genomics for Animal Health (AGAH 2010) \\ Paris, France. 31 May - 2 June 2010
}

\begin{abstract}
Background: In previous studies, the Mx Gene has been demonstrated to confer positive anti viral responses in chicken. The amino acid variation of Asn (allele A) at position 631 was specific to positive antiviral Mx/resistant, while, that of Ser (allele G) was specific to negative Mx/susceptible. This research was aimed at selecting one of the native chicken breeds which was found out to be resistant to avian influenza using molecular technique. The selected breed will then be used as the base population to improve native chicken breed in Indonesia.

Methods: Marker Assisted Selection (MAS) method was used in this research to accelerate the selection process, since the disease resistance had low heritability value. Polymerase Chain Reaction-Restriction Fragment Length Polymorphism (PCR-RFLP) technique used to select the genotype of $\mathrm{Mx}^{++}, \mathrm{Mx}^{+-}$and $\mathrm{Mx}^{-}$that corresponded to the positive antiviral activity $\left(\mathrm{Mx}^{++}\right)$, or those which had positive or negative activity $\left(\mathrm{Mx}^{+-}\right)$and negative antiviral activity $\left(\mathrm{Mx}^{-}\right)$. There were 200 native hens and 40 cocks used in this experiment. Allele frequency of Mx Gene was calculated. The productivity indicators such as age at first laying, egg weight and hen weight at first laying and egg production were also measured. The chicken that had $\mathrm{Mx}^{++}$and $\mathrm{Mx}^{+-}$genotypes, were selected to produce offspring.

Results: Result showed that the frequency of the resistant allele $\left(\mathrm{Mx}^{+}\right)$was $65 \%$ and $60 \%$ in laying hens and in cocks, respectively, while the frequency of the susceptible allele (Mx-) was $35 \%$ and $40 \%$ in hens and cocks, resepctively. Age, egg weight and hen weight at first laying and egg production for susceptible genotype were slightly better than for the resistant genotype which were 172,41 VS 178,81 days; 33,94 VS 32,84 g; 1450 VS $1439 \mathrm{~g}$ and 54,32 VS $48,30 \%$, respectively.
\end{abstract}

\section{Background}

Indonesia has many varieties of native chicken. Based on phenotypic performances there are more than 32 distinctive breeds that are being raised under extensive and/or intensive systems [1]. Estimated population was about 230 millions. In Indonesia, meat from native chicken is more expensive than from commercial hybrid chicken. The consumers like to pay more as it is tastier

\footnotetext{
* Correspondence: tikesartika@hotmail.com

+ Contributed equally

'Indonesian Research Institute for Animal Production (IRIAP), PO BOX 221-

Bogor 16002, Indonesia

Full list of author information is available at the end of the article
}

and low fat content. The native chicken eggs are also more expensive than commercial chicken eggs, because it can be used as part of traditional herbal drink call "Jamu", which is very popular in Indonesia.

Since 2003, Indonesia has outbreaks of Avian Influenza (AI). Naturally, native chicken has ability to resist the virus controlled by antiviral genes. The Mx proteins are key components and its coding protein had been shown to be induced by interferon (IFN) and to inhibit the replication of RNA virus [2]. Their genetic resistance was shown to result from the difference in genomic structure of the Mx gene. Watanabe [3] studied chicken Mx cDNAs from other breeds to see whether these 
chickens carried resistant or sensitive character of the $\mathrm{Mx}$ gene to the VSV/vesicular stomatities virus infection, as compared with the differential antiviral activity with amino acid substitutions at 15 positions. Only an amino acid substitution at position 631 was identified to determine the difference between the antiviral activity of chicken Mx protein; Asparagine (Asn) corresponded to the positively antiviral activity and serine (ser) corresponded to the negatively antiviral activity [2-4]. The chicken Mx protein spans about 2,118 bp, with 13 exons on chromosome 1 of the chicken genome. A total of 237 single nucleotide polymorphisms were found in the chicken $\mathrm{Mx}$ gene by comparison among 4 directly sequenced Mx genomic DNA sequences. In this study, identification of $\mathrm{Mx}$ gene by mismatching PCR-RFLP method can discriminate whether the chicken carry positive or negative virus activity. Sulandari et al[5] reported the study of 485 samples from 15 breeds of Indonesian native chicken by a specific PCR-RFLP technique showed that the averaged frequency of resistant allele $\left(\mathrm{A} / \mathrm{Mx}^{+}\right.$allele) was $62.73 \%$ and that of sensitive allele ( $\mathrm{G} / \mathrm{Mx}^{-}$allele) was $37.27 \%$. Investigation of distribution of the allele $\mathrm{A}\left(\mathrm{Mx}^{+}\right)$and $\mathrm{G}\left(\mathrm{Mx}^{-}\right)$on chickens has been also reported [2,3,6-9].

The aim of the research was to examine the proportion of allele frequency of Indonesian Native chicken, especially Kampung chicken at breeding population in IRIAP (Indonesian Research Institute for Animal Production). Selection using resistant $\mathrm{Mx}$ gene is effective for breeding program to increase selected breed as resistant to RNA virus.

\section{Methods}

A total of 240 samples (200 hens and 40 cocks) from one of the native chickens in Indonesia (Kampung chicken, selected for egg production for 6 generations) were used in this study. The fresh blood from chickens was collected and preserved in 96\% absolute alcohol. Genomic DNA was extracted from whole blood using the phenol-chloroform method [10]. PCR-RFLP method was used to genotype the G/A SNP at nucleotide position 1,892 in the $13^{\text {th }}$ exon of coding sequence of the Mx gene using PCR-RFLP mismatched primers. The mismatch primer sequences [8] which amplify approximate $100 \mathrm{bp}$ long fragment were as follows: Forward primer NE-F2 (5'CCTTCAGC CTGTTTTTCTCCTTTTAGGAA3') and Reverse primer NE-R2/R (5'CAGAGGAATCTGATTGCTCAGGCGT GTA3') or Reverse primer NE-R2/S (5'CAGAGGAATCTGATTGCTCAGGCGAATA3'). The Rsa1 restriction enzyme was used with a recognition sequence of 5'GT $\downarrow A C 3$ ' to cut the fragment at the position of interest when there is an allele G using primer NE-F2 and NE-R2/ $\mathrm{R}$, while the Ssp1 restriction enzyme was used with a recognition sequence of 5'AAT $\downarrow$ ATT3' to cut the fragment at the position of an allele A using primer NE-F2 and NE-R2/S.

The following PCR condition was used: an initial denature at $94^{\circ} \mathrm{C}$ for $5 \mathrm{~min}$, followed by 35 cycles of $60 \mathrm{~s}$ at $94^{\circ} \mathrm{C}$, annealing temperature for $60 \mathrm{~s}$ at $60^{\circ} \mathrm{C}$, and $72^{\circ} \mathrm{C}$ for $60 \mathrm{~s}$, and final extension at $72^{\circ} \mathrm{C}$ for $5 \mathrm{~min}$. PCR product were analyzed by electrophoresis through $2 \%$ agarose gel in $1 x$ TAE buffer, and stained with ethidium bromide. Amplicons were cleaved with the restriction enzyme the Rsa1 and/or Ssp $1(1 \mathrm{U} / \mu \mathrm{g})$ for $6-8$ hours at $37^{\circ} \mathrm{C}$ following the manufacture's instruction. The digested fragments were visualized by $12 \%$ polyacrylamide gel in constant voltage 160 volt for 4 hours. The gel was stained with silver nitrate [11] and scanned using Adobe Photoshop.

Allele frequencies were calculated for hens and cocks. Productivity such as age, egg weight and hen weight at first laying and egg production based on genotype $\mathrm{Mx}$ gene were analysed using Anova, Minitab V.14.

\section{Results and discussion \\ Mx gene genotyping}

The genomic DNA of 200 hens and 40 cocks were successfully amplified. Identification of resistant and sensitive chicken Mx gene was examined by mismatch PCRRFLP. The PCR product was cleaved with the restriction enzyme of the Rsa1 and the digested showing polymorphism bands, one band with $100 \mathrm{bp}$ in length (A/A, homozygous resistant $\mathrm{Mx}$ allelic genes); two bands with $100 \mathrm{bp}$ and $73 \mathrm{bp}$ in length (A/G, heterozygous Mx allelic genes); and one band with $73 \mathrm{bp}$ in length $(\mathrm{G} / \mathrm{G}$, homozygous sensitive $\mathrm{Mx}$ allelic gene). An example of genotyping results is presented in Figure 1, and corresponding allele frequency is presented in Table 1.

As shown in Table 1, results from the 240 samples by specific PCR-RFLP indicate a polymorphism at the Mx gene (which is putatively associated with AI resistance/

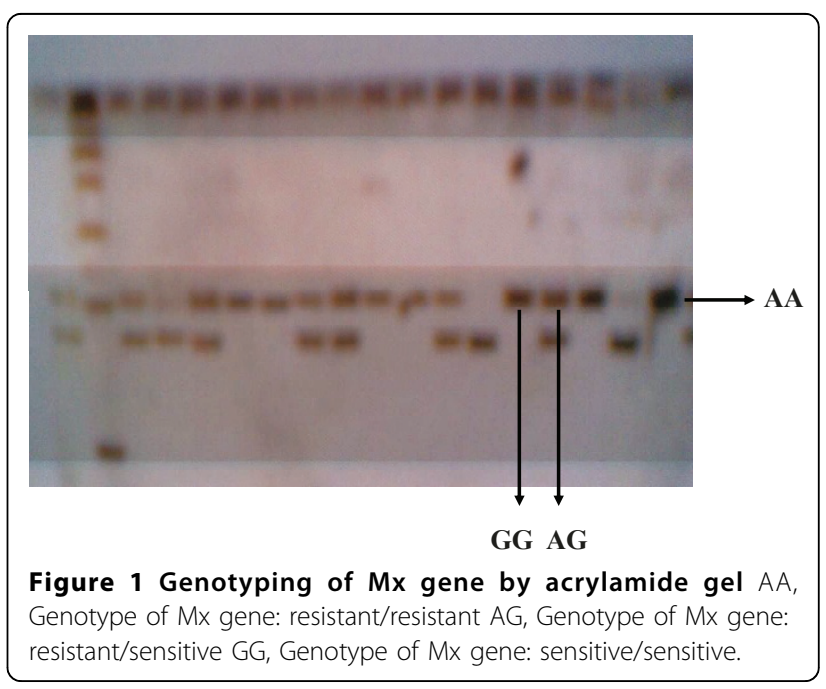


Table 1 Frequency of allelic hen and cock native chicken

\begin{tabular}{|c|c|c|c|c|}
\hline \multirow[t]{2}{*}{ Samples } & \multirow[b]{2}{*}{$\mathrm{AA} / \mathrm{Mx}^{++}$} & \multicolumn{2}{|c|}{ Genotype } & \multirow[t]{2}{*}{ Frequency of allele } \\
\hline & & $\mathrm{AG} / \mathrm{Mx}^{+-}$ & $\mathrm{GG} / \mathrm{Mx}^{-}$ & \\
\hline Hens native chicken (200) & 80 & 102 & 18 & $\begin{array}{l}f(A)=0,65 \\
f(G)=0,35\end{array}$ \\
\hline Cocks native chicken (40) & 15 & 18 & 7 & $\begin{array}{l}f(A)=0,60 \\
f(G)=0,40\end{array}$ \\
\hline
\end{tabular}

susceptibility in chicken). The frequency of the resistance allele (A allele) for the hen native chicken was $65 \%$, while for cock native chicken was $60 \%$, and that for sensitive allele ( $G$ allele) was $35 \%$ for hen and $40 \%$ for cock native chickens. Investigation of the distribution of the allele $A$ and $G$ on chickens has also been reported [2,3,5-8,12]. As reported by Sulandari et al., [5],Indonesian native chicken had averaged frequency of resistant allele (A allele) of $62.73 \%$ and sensitive allele (G allele) of $37.27 \%$. A representative various breed of Indonesian native chicken such as White Kedu, Golden Arab, Sentul, Dwarf, Black Kedu, Pelung, Gaok, Kalosi, Tolaki, Merawang, and Cemani chickens, tend to have a higher frequency of the resistant allele. Frequency of A allele in each breed was $0.58,0.62,0.63,0.66,0.68,0.69$, $0.70,0.70,0.74,0.81$, and 0.87 respectively, while Kapas, Wareng, Nunukan and Silver Arab chickens, as founder

Table 2 The productivity of hen native chicken for $\mathbf{1 0}$ weeks at 1 st periods lay

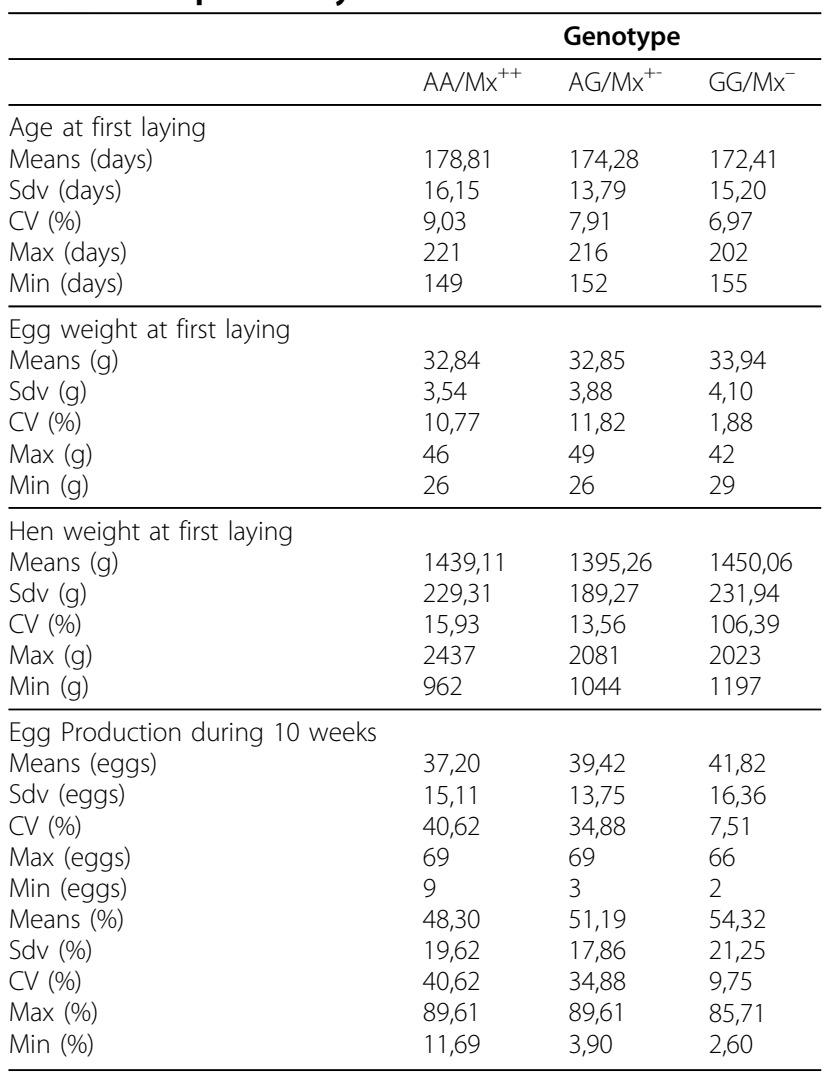

local chicken, had a higher frequency of the sensitive allele, with a frequency of A allele of 0.32, 0.44, 0.45, and 0.47 respectively.

\section{Productivity of native chicken}

The productivity of native chicken was divided by 3 groups for the Mx genotype presented (Table 2). Statistical analyses showed that for all traits no significant effect of the genotype. However, descriptively the GG genotype birds carrying the sensitive allele were relatively slightly better than those carrying the AG/resistant and sensitive allele and AA genotype/resistant allele. Age at first laying in GG genotype was lower than the AG and AA genotype. Similarly, egg weight, hen weight at first laying and egg production was better in GG genotype.

Hen day production curve was presented in Figure 2. Based on genotype Mx gene, hen day peak production of hen with GG genotype (64\%) was slightly better than of hen with AA and AG genotype (60\%). Egg production of native chicken in this study was better than in common native chicken (28\%) in Indonesia [13]. Overall, the results indicated that the sensitive allele/ GG genotype tended to be better in productivity than the resistant allele/AA genotype.

\section{Conclusion}

In conclusion, the frequency of $\mathrm{Mx}^{+}$gene (A allele) in Indonesian native chicken was relatively high. The

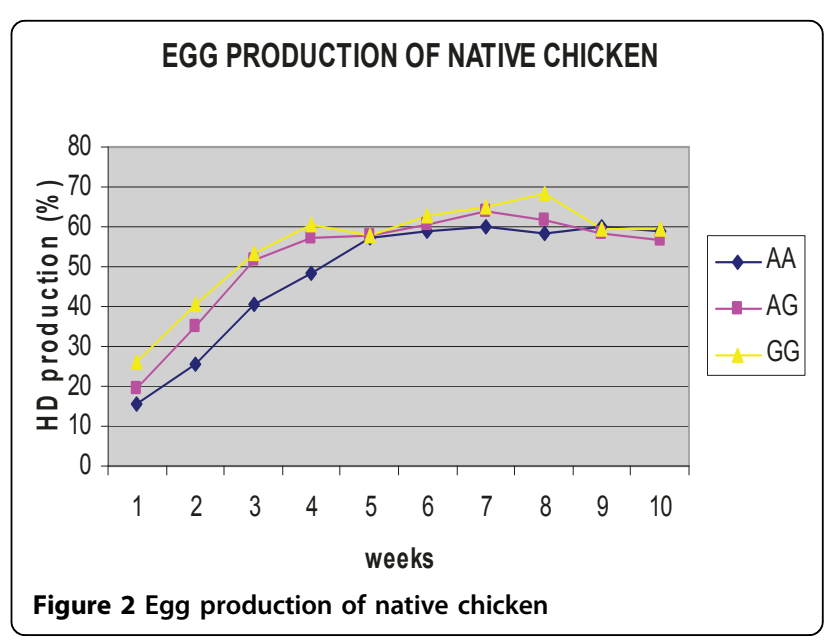


productivity of native chicken measured as age, egg weight, body weight at first laying and 12 weeks egg production didn't differ significantly between $\mathrm{Mx}$ genotypes.

\section{Acknowledgements}

This article has been published as part of BMC Proceedings Volume 5 Supplement 4, 2011: Proceedings of the International Symposium on Animal Genomics for Animal Health (AGAH 2010). The full contents of the supplement are available online at http://www.biomedcentral.com/1753$6561 / 5$ ? issue $=$ S4

\section{Author details}

'Indonesian Research Institute for Animal Production (IRIAP), PO BOX 221

Bogor 16002, Indonesia. ${ }^{2}$ Research Centre for Biology, The Indonesian

Institute of Sciences (LIPI), Cibinong 16911, Indonesia.

\section{Competing interests}

The author(s) declare that they have no competing interests.

Published: 3 June 2011

\section{References}

1. Sartika T, Iskandar S: To be Known Germ Plasm of Indonesian Chicken an Its Utilization. Indonesian Research Institute for Animal Production (IRIAP), Bogor-Indonesia;Diwyanto K 2007:

2. Ko JH, Jin HK, Asano A, Takada A, Ninomiya A, Kida H, Hokiyama H, Ohara M, Tsuzuki M, Nishibori M, Mizutani M, Watanabe T: Polymorphisms and the differential antiviral activity of the chicken $\mathrm{Mx}$ gene. Genome Res 2002, 12:595-601.

3. Watanabe T: Genetic analysis of antiviral resistant $\mathrm{Mx}$ gene in the chicken. International Workshop on Animal Genome Analysis Zuihou-no-ma KKR Hotel Tokyo; 2003.

4. Li XY, Qu LJ, Hou ZC, Yao JF, Xu GY, Yang N: Genomic structure and diversity of the chicken Mx gene. Poult Sci 2007, 86:786-789.

5. Sulandari S, Zein MSA, Astuti D, Sartika T: Genetic polymorphisms of the chicken antiviral Mx gene in a variety of Indonesian indigenous chicken breeds. J Veteriner 2009, 10(2):50-56.

6. Balkisson D, Staines K, McCauley J, Wood J, Young J, Kaufman J, Butter C: Low frequency of the $\mathrm{Mx}$ allele for viral resistance predates recent intensive selection in domestic chicken. Immunogenetics 2007, 59:687-691.

7. Li XY, Qu LJ, Yaou JF, Yang N: Skewed allele frequencies of an Mx gene mutation with potential resistance to avian influenza virus in different chicken population. Poult Sci 2006, 85:1327-1329.

8. Seyama T, Ko JH, Ohe M, Sasaoka N, Okada A, Gomi H, Yoneda A, Ueda J, Nishibori M, Okamoto S, Maeda Y, Watanabe T: Population research of genetic polymorphism at amino acid position 631 in chicken Mx protein with differential antiviral activity. Biochem Genet 2006, 44:437-448.

9. Watanabe T: Polymorphisms of the chicken antiviral Mx gene. Cytogenetic and Genome Research 2007, 117:370-375.

10. Sambrook J, Fitsch EF, Maniatis T: Molecular Cloning: A Laboratory Manual. Cold Spring Harbor, Cold Spring Harbor Press; 2001.

11. Sulandari S, Zein MSA: Practical Manual of DNA Laboratorium. Research centre for Biology, The Indonesian Institute of Sciences (LIPI), Cibinong, Indonesia; 2003.

12. Maeda Y: Polymorphism of Mx gene in Asian indigenous chicken population. International Symposium of local poultry in Indonesia Diponegoro University, Central-Java-Indonesia; 2005.

13. Sartika T: Quality improvement of the Kampung chicken by selection and the investigation on the use of the prolactine promoter gene for marker assisted selection (MAS) to accelerate selection progress. $\mathrm{PhD}$ thesis Bogor Agricultural University, Animal Science Department; 2005.

doi:10.1186/1753-6561-5-S4-S37

Cite this article as: Sartika et al:: Selection of Mx gene genotype as genetic marker for Avian Influenza resistance in Indonesian native chicken. BMC Proceedings 2011 5(Suppl 4):S37.

\section{Submit your next manuscript to BioMed Central and take full advantage of:}

- Convenient online submission

- Thorough peer review

- No space constraints or color figure charges

- Immediate publication on acceptance

- Inclusion in PubMed, CAS, Scopus and Google Scholar

- Research which is freely available for redistribution 